\title{
Art Perform in Saung Angklung Udjo as Memorable Tourism Experience
}

\author{
Laras Ramadhania Putri*, Trianti Nugraheni, Juju Masunah \\ Program Studi Pendidikan Seni \\ Universitas Pendidikan Indonesia \\ Bandung, Indonesia \\ *banabana.ba18@gmail.com
}

\begin{abstract}
This research was conducted to find out how the Performing Arts at Saung Angklung Udjo became an Art Tourism in Bandung. The aim is to examine how the art performance presented at Saung Angklung Udjo and how the art performance becomes an attractive tour for local and foreign tourists. This study uses a qualitative research design and descriptive analysis method, researchers obtain data and examine it further for analysis. Data obtained from research instruments namely observation, interview, literature review and study documentation. After the data is obtained, its validity will be processed by triangulation. Findings of this research show that Saung Angklung Udjo not only displays angklung performances, but also presents other art performances such as dance and puppet show demonstrations, involved the visitors in the angklung show, giving tourists the direct experience of playing angklung. Saung Angklung Udjo is one of the biggest and most well-known art tourism destinations in Bandung which also supports the tourism sector in Bandung.
\end{abstract}

Keywords-performing arts, Saung Angklung Udjo, tourism, Bandung City

\section{INTRODUCTION}

As a big outlined, art performance has three primary functions, namely as a means of ritual, as a personal expression of personal entertainment and as an aesthetic presentation [1]. Art performance that function as a means of aesthetic presentation must be very neatly packaged, starting from costume, make-up, artistic arrangements, and so on. Narawati explains about the division of primary functions into three based on "who" is the connoisseur of the art performance [2]. This is important for us to give attention to, because art performances are called because art performances because they are performed for the audience.

Saung Angklung Udjo certainly has its own audience, the public and tourists are part of the connoisseurs of the show, so realize that "who" is the audience for the art performances at Saung Angklung Udjo are visitors who are on a tour to Bandung city. Saung Angklung Udjo provides a valuable experience for the tourists to watch, get to know, and even play angklung together. So it can be concluded that Saung
Angklung Udjo is one of the tourist destinations that has a cultural tourist attraction.

According to the Law of the Republic of Indonesia Number 10 of 2009 concerning tourism, a tourist attraction is anything that is unique, beautiful and valuable in the form of a diversity of natural, cultural and man-made wealth, that is the target or purpose of tourists visit. The condition of nature, flora and fauna, as a gift from God Almighty, as well as historical ancient, artistic and cultural heritage owned by the Indonesian people are the resources and capital for tourism development to increase the prosperity and welfare of the people as contained in Pancasila and the Preamble of Laws. The basis of the Republic of Indonesia in 1945 as follows.

Culture has a very important role in tourism, one of which causes people want to do the art travel is the desire to see the way of life and culture of other people in other parts of the world and the desire to learn about other people's cultures. The tourism industry recognizes the role of culture as a pull factor by promoting the cultural characteristics of destinations. Cultural resources are likely to be the main factors that attract tourists to travel [3].

Based on this, it can be examined that culture is one of the important factors that can attract the attention of local and foreign tourists to come to an area that has its own uniqueness, making them have new experiences and knowledge that they can later bring and tell about their respective areas and not immediately became an invitation to the others. To be able to attract the attention and visits of foreign tourists, performers must be able to know the tastes of these tourists, this is explained by Soedarsono where art develops and experiences different metamorphoses from art created for the benefit of society [1].

Saung Angklung Udjo is a tourism destination in the form of a Limited Liability Company or PT which was founded by Udjo Ngalagena and his wife Uum Sumianti in 1966. Saung Angklung Udjo has the goal of preserving Sundanese Cultural Arts, especially Angklung musical instruments which are packaged in a show to entertain tourists both local and foreign 
because the performances that are displayed at Saung Angklung Udjo are bilingual.

Angklung adalah alat musik terbuat dari bambu yang memiliki dua sampai tiga tabung tergantung pada rangka dan dimainkan secara digoyang, ditengkep, atau digetarkan. Sejak tahun 2010, angklung telah diakui oleh UNESCO sebagai warisan budaya dunia 'tak benda' dari Indonesia. Di Saung Angklung Udjo dikenal angklung Sunda dan angklung Indonesia [4].

Angklung is a musical instrument made of bamboo which has two to three tubes depending on the frame and is played by shaking, tapping, or vibrating.

Since 2010, angklung has been recognized by UNESCO as an 'intangible' world cultural heritage from Indonesia. In Saung Angklung Udjo there are Sundanese and Indonesian angklung [4].

Tourists who travel to cultural tourism tend to be motivated by educational motives and the search for something new $[5,6]$ they may not return to these tourist destinations as often as other tourists, even though they enjoy the experience. However, the market for cultural tourism is also recognized as heterogeneous $[7,8]$.

According to Chandralal and Valenzuela, a memorable travel experience affects behavioral outcomes, such as interest in returning to or recommending memorable trips and destinations to others [9]. As a leading cultural tourism destination, Saung Angklung Udjo must be able to provide a memorable experience to its visitors so that they will have the desire to visit again. Therefore, researchers used the theory of memorable tourism experience to measure its influence on the value of Art Education Tourism for visitors to Saung Angklung Udjo.

Chandralal and Valenzuela suggest that Memorable tourism experience consists of eight dimensions, namely perceived meaningfulness, perceived opportunities for encountering authentic local experiences, perceived significance, perceived novelty, perceived opportunities for social interaction, perceived local hospitality, unplanned discoveries and surprises (serendipity and surprises), and the perceived professionalism of local guides [9]. These eight dimensions can be found in Saung Angklung Udjo which will be explained in this article. Where Saung Angklung Udjo fulfills the dimensions of the Memorable Tourism Experience and this is found in the art performances presented.

\section{RESEARCH SubJeCT AND MEthods}

This article is the result of a research conducted with a qualitative approach by focusing how the art performances at Saung Angklung Udjo are performed. A qualitative approach is a method for exploring and understanding the meaning that a number of individuals or groups of people think comes from social problems [10]. This article is a description, as explained by Neuman [11], that descriptive research is research that presents a specific picture of situations, social arrangements, or relationships. This research was conducted at SAU, Jalan Padasuka No. 118, Bandung, West Java. The participants in this study were tourists who visited Saung Angklung Udjo.

In this study, the sampling technique was accidental sampling, namely the sampling process was carried out without careful planning. Respondents who were asked for information happened to be met at the time of conducting the research, actually done by chance and with certain considerations. By using this method, the respondent who responds is determined by chance [12].

Primary data obtained by researchers through observations and interviews with informants, there are students from Lampung and Central Java. Secondary data in this study were obtained through literature study activities, in the form of searching documents containing facts, articles or references, and other materials that support this article.

The preliminary analysis obtained from the first research, there are the students from Lampung and Central Java, were both at the same time touching and even seeing angklung directly, they said that this was a quite memorable experience because usually they only saw angklung in textbooks and 1000 rupiah coins. In addition, they did not expect to be directly involved in angklung performances and invited to dance to the stage arena. At the first glance, it can be seen that the art performance at Saung Angklung Udjo is a memorable thing for tourists, especially outside West Java. Next, we will discuss what are the art performances at Saung Angklung Udjo look like and whether the performances fulfill the eight dimensions of memorable tourism experience or not, which will be discussed further in.

\section{RESULTS AND DISCUSSION}

The various efforts made by Udjo and the community in its development have had an impact on the development of various other traditional artistic creativities. Not only angklung and its performances have developed, other traditional arts have also developed such as various musical instruments made of bamboo (arumba: strains of bamboo clumps), namely musical performances of various musical instruments made of bamboo, many musical groups are born using bamboo as a tool. The main music, wearing Sundanese traditional clothes in daily activities, preserving the tradition of circumcision ceremonies (helaran) in Sundanese, preserving traditional music and songs, traditional dances, puppet art, and exploring the values of Sundanese philosophy of life, ethics and spirit of Sundanese culture. others through the bamboo and angklung philosophy implemented in the learning process at SAU.

One of Udjo Ngalagena's goals in establishing SAU is of course to preserve the art of Angklung. Introducing through tourism with attractive packaging and providing education about Sundanese art through tourism packaging.

Educational tourism is a program in which participants in tourism activities take a tour in a certain place in a group with the main objective of gaining of learning experiences directly 
related to the location that visited [13]. Educational tourism is a tourism activity carried out by tourists who take a day's vacation and those who travel for education and learning as the main or second goal.

From this explanation, it is clear why SAU is often the destination of school tours even from outside West Java. Saung Angklung Udjo provides a direct experience of learning Sundanese arts with art performances that even involve tourists.

\section{A. Arts Performance Performances Presented By SAU}

1) Demonstration of Wayang Golek: Wayang Golek typical of Sundanese land, it is the performance of wooden puppet plays that resemble a human body complete with costumes, which at first were often performed as part of traditional ceremonies such as: bersih desa ceremony, ngaruat, etc., by a puppeteer. Reviewed from its philosophy, the word wayang which means shadow, is a reflection of the qualities in the human soul, such as anger, virtue, greed, etc. In each of its performances, wayang always carries a moral message so that we always obey the creator and do good things to others. At the performance on December 14th, 2019, the researcher appreciated this puppet show, and at that time the puppeteer inserted a dialogue about the 9 year compulsory education which coincided with the audience who came from the education sector.

Generally, the puppet show lasts more than 7 hours, namely at night, all night around 20.00 - 21.00 until 04.00. In SAU, there will only be demonstrations of wayang golek, which include demonstrations of how the puppets talk, dance and fight. The puppeteers who played at SAU were Mr. Ade Kosasih Sunary from Padepokan Giri Harja and Mr. Dede Amung Sutaraya from Padepokan Munggul Pawenang. The language used by the puppeteer in this performance is a mixture of Sundanese, Indonesian and English because visitors who come from various layers of tourists, however, Sundanese language remains the dominant language used.

2) Helaran: After the demonstration, Helaran is performed. Helaran is usually played for traditional circumcision ceremonies and rice harvest ceremonies. Because it aims to entertain and give thanks to God, the music is uplifting and cheerful. The angklung used for Helaran is the angklung that has a pentatonic tone. Children aged 4-15 years are a part of this show.

The Helaran began with a procession of children carrying angklung, then a procession of boys who were carried on bamboo chairs raised by 4 adults and covered by golden umbrellas. This boy describes a boy who is being circumcised. Therefore this sheet is a copy of the procession of boy who has just been circumcised. In the original Sundanese tradition of circumcision, it is usually done one day before the day of circumcising the child. The day before the circumcision, the boy will be paraded around the village like a little king. The child, also known as the bride, is paraded on a small, decorated stretcher in such a way. The parading is usually family members, relatives, and neighbors.

The group of the circumcision bride toured the village accompanied by lively Sundanese art. There are those who use tanjidor art, which is a traditional orchestra from the Betawi Tribe in the Bekasi area using wind, string and percussion musical instruments. There are also those who parade with enlivened artistry in the Subang area.

Sisingaan is a Sundanese art that uses a stretcher in the shape of a lion's head and body. In a circumcision party that uses sisingaan, the boy who will be circumcised is paraded on the lion's stretcher. In addition, there are also those who parade by performing the art of Renggong Kuda in Sumedang and Majalengka areas. Kuda Renggong is a Sundanese art where horses have been trained to be able to walk to the rhythm of the music while supporting a circumcised bride. The party to parade the bride and groom is done so that the child feels happy and is not afraid to be circumcised.

After the parade party, a thanksgiving event was held for the child to be circumcised in the evening. At the family thanksgiving ceremony, the child invites neighbors and big families to read the prayers for the safety of the child. In thanksgiving, a family banquet is usually held. Then the next morning, the child who is going to be circumcised is usually put in the cold water so that he is numb or immune. Immediately after being immune the child was circumcised. Some use the services of a spell, some go to a doctor.

After being circumcised, another party was held for the circumcised bride so that he would forget the pain of being circumcised. At this time, usually neighbors and family relatives will greet the boy and give him money which in Sundanese is called nyecep. The nyecep is given so that the child stops crying and feels happy. After that, in the evening a Sundanese art performance is held in the yard of the circumcision bridal house. Sundanese arts that are commonly performed are the jaipongan dance, wayang golek, and wayang kulit. This is described in Helaran at SAU. Not only parading the child who is being circumcised, but other children also play angklung, and there are also some children who dance in pairs, similar to the ketuktiluan movement, which describes the excitement of imitating the original form of the dish.

3) Mask dance: A typical Cirebon dance that is danced by women. First they will dance without wearing a mask. The story goes that the spy from Majapahit was investigating the state of the Blambangan Kingdom. Then they began to dance wearing masks in a way that the spy disguised himself as a manly man to fight against King Menak Jingga. The red mask symbolizes the temperamental character. Similar to the puppet show demonstration, the mask dance that is presented is not a form of a complete dance presentation, the dance presented is only a few sentences of motion, to suit the duration of the performance.

In a study by Herlandra, with the title Kandaga Mask Dance by Abah Sardi at Saung Angklung Udjo, it was 
explained that this Kandaga Mask dance was a form of mask dance developed by the late [14]. Abah Sardi which was based on external factors, namely Mang Udjo's request as the founder of Saung Angklung Udjo to involve dance in the show which will be held at Saung Angklung Udjo. In the process of creating the Kandaga Mask dance, Mang Udjo wanted something different in the show, which was until finally Mang Udjo asked Abah Sardi to develop the movements of the Mask dance which eventually created the Kandaga Mask Dance which was the complete work of Abah Sardi's creativity. This dance is a form of Mask dance that is unique in it, such as the creation background, choreography structure, and the function of the Kandaga Mask dance itself. As for the unique movements contained in this dance, the movement of ngageulis motion is a dance move that look like it to mirroring, and the picking flowers motion, which is a dance move that look like to picking flowers, the movement of ngageulis and picking flowers should be felt to be accurate to the characters contained in the Topeng Kandaga dance.

Furthermore, the function of the Topeng Kandaga dance, this dance is created with the aim of being one example of a dance in West Java which will eventually be performed at the end in a series of angklung performances at Saung Angklung Udjo. Until now, the function of the Topeng Kandaga dance is as a performance, entertainment or public spectacle where this dance is one example of art found in West Java in the field of dancing, so that in its performance the Kandaga Mask dance does not have a special role, returning to Mang Udjo's goals. Mang Udjo the founder Saung Angklung Udjo wanted to make Saung Angklung a place for the arts of West Java without neglecting the educational side contained in each of his performances.

4) Angklung orchestra: Angklung is not only used to accompany Sundanese songs. In this angklung orchestra, various types of songs will be played, from Balonku, TwinkleTwinkle Little Star, to dangdut songs and Indonesian folk songs. The angklung playing is combined with musical instruments such as guitar, percussion, etc. Angklung can play almost all types of songs, classic, contemporary, pop, as well as accompanying vocals. On the one hand, the specialty of angklung is that it is a very interesting musical instrument performed with a lot of people, on the other hand, a good angklung game will be created if there is solidarity among the players. In this angklung orchestra, a player plays not only one note but the whole tone, this is an innovation of modern angklung. The players are not only adult men, but also young men and women who study in the studio. At the orchestra attraction, the angklung is played together by the performers to produce a beautiful sound.

5) Playing angklung together: The audience was also given the opportunity to play angklung. The children under the guidance of Saung Angklung Udjo will lend them the angklung with various numbers given by the SAU children. With guidance and instructions from Saung Angklung Udjo, in a very short time, the audience can play several songs with the angklung. One of the songs played was Ambilkan Bulan Bu. On December 14th, 2019, the instructor who gave the instructions was Atika Bestari.

The visitors are invited to participate in playing angklung. Every visitor is given the angklung with a specific note. Then, the presenter starts guiding the visitors who are already holding the angklung, by asking them to sound the angklung in order of tone, starting from do, re, mi and so on. After the visitors get used to and memorize which tone he is holding on, start this game of angklung together. The Master of Ceremony simply shows the code through his hand, for example the number one for the tone Do, two for the tone Re, three for the tone Mi, and so on. Until finally a song was formed which was entirely played by visitors to Saung Angklung Udjo.

6) Dancing Together: At the end of the event, the children who joined Saung Angklung Udjo will invite the audience to dance and sing together. In this session, visitors are invited to dance a traditional West Java dance. Visitors can follow dance movements driven by dancers and mingle together. At the first glance, dancing together looks like a Bajidoran show when the community mingles dancing together. The interactions that occur between the dancers and the audience as well as between the audience and the audience become a direct experience for the tourists to get memories of dancing to the accompaniment of Sundanese songs.

Tourism Art Performance is a Memorable Tourism Experience for the Tourists. This activity educates visitors to introduce Sundanese culture. The activity is amusing because it is accompanied by cheerful music. The attraction is usually in the last session of the show schedule every day.

The researcher interviewed two students who came from two different regions, namely Bandar Lampung and Blitar, East Java. They came to Bandung to carry out a Study Tour with their school group. After the show was over, they felt the same feeling, which was memorable. The impression that arises is an experience that they have never felt before, when it was the first time they saw and played angklung, an angklung that they had only seen in school textbooks, and finally they could play it. Furthermore, the most memorable impression was when they could dance together accompanied by gamelan and bamboo music, they moved their bodies with the dancers at SAU.

The incidental samples obtained describe the art performances at SAU as a memorable tourism art performance, and become the reason why this tourism art performance becomes a memorable tourism experience.

Masunah states that art tourism is a tourism event in which art is the destination of tourist visits, while tourism art is an art that takes a short time, varies art material, is presented attractively, cheap, and its symbolic or sacred elements are removed [15]. In the context of art tourism, one of the offerings of art tourism is an artistic creativity that the aims to be sold to the tourists. 
This statement is also in line with the characteristics of the art performance described by Soedarsono [1], there are:

- An imitation of the original

- Short or compact version

- The sacred, magical, and symbolic values are removed

- Full of varieties

- Showed attractively

- Cheap price according to the pocket of the tourists

Reviewed from the six points, Saung Angklung Udjo fulfills the characteristics of the show which is specially packaged for tourism needs. In the show, there is a copy of the helaran circumcision that tries to imitate the original. In the helaran, a child is displayed who is the icon of the circumcision party. Furthermore, in his performance, SAU "condensed" his appearance is to the effectivenes to the time and conform to these characteristics. This can be seen clearly in the performance of the wayang golek demonstration which is only shown for about 20 minutes, while in the original wayang golek performance it usually takes up to hours all night long.

In addition to the wayang golek (puppet show) demonstration, SAU also "trimmed" a mask dance that was supposed to last 20 minutes into a mask dance performance that lasted about 5 minutes. According to Sihite tourism is a journey that people take for a while from one place to another [16]. This is the main reason why one of the characteristics of tourism performing arts is short and dense, it is because tourists do not have much time and must continue their journey.

As previously mentioned, the appearance of art for tourism has lost its sacred, magical and symbolic value. In SAU's performance, we don't find anything sacred or magical in it.

Soedarsono stated that the theory of performing arts and tourism in the era of globalization is metamorphosis art (art by metamorphosis), also known as art of acculturation, because the performing arts in its cultivation have undergone an acculturation process [1]. The acculturation occurs between the aesthetic tastes of local artists and the tastes of tourists. The art of acculturation of this kind is also referred to as pseudotraditional art (pseudo-traditional art) because its form still refers to traditional forms and principles, but traditional values which are usually sacred, magical, and symbolic have been ignored or made up.

Saung Angklung Udjo, featuring a very interesting variety of displays. The event was presented in two languages (Indonesian and English) so that it was understood locally and internationally. The colorful costumes, coupled with the boisterous bamboo music, make for a festive and interesting atmosphere. Moreover, SAU provides direct experience for the audience to be able to play angklung. The varied dishes (wayang, dances, music) made the audience not bored watching the performance.
The prices set by SAU range from Rp.50,000 - 75,000 for local tourists and Rp.70,000 - 120,000 for foreign tourists. The price is quite affordable for a very good performance. Besides getting the opportunity to watch the performance, tourists who come will get an angklung necklace as a souvenir when exchanging the tickets. This price is quite affordable for the price range of tourist attractions in Bandung City, so that, SAU is often a tourist destination for groups of students from around West Java and even outside the Province.

The six characteristics of tourism art put forward by Soedarsono are fulfilled by the art performance at Saung Angklung Udjo, which indicates that the performance at SAU is a tourist art performance [1].

\section{B. Memorable Tourism Experience of SAU}

This art performance is a special experience and memories for tourists. One of the tourism theories which is also the purpose of this research is to see whether memorable tourism experience is found in art performances at Saung Angklung Udjo. Memorable tourism experience has 8 dimensions that researchers will compare with the field conditions in SAU.

- Perceived meaningfulness. Sundanese art performances, added with an atmosphere that supports the taste of Sundanese. For the researcher itself, she feels that SAU gives a strong meaning about Sundanese culture and art which tries to be highlighted in addition to business and tourism purposes, as well as to preserve the angklung art. The arrangement of the performance arena which is mostly made of bamboo, all visitors get a souvenir angklung necklace, and memorable dishes, which have a meaning that will be remembered. One of them was during the Wayang Golek show, the puppeteer delivered a narrative that was not only entertaining but also gave meaningful messages. When researchers came to watch the SAU performance in December 2019, the puppeteer inserted the 9-year compulsory education dialogue and gave a message to visitors about.

- Perceived opportunities for encounter authentic local experience. Yulianto stated that culture has a very important role in tourism, one of the reasons why people want to travel is the desire to see the way of life and culture of other people in other parts of the world and the desire to learn about other people's cultures [3]. SAU presents authentic Sundanese culture, cannot be found outside of Sundanese land.

- Perceived significance, interviews conducted with the students from Blitar and Lampung in December 2019, they said that the performance at SAU was very different from the performances they had seen. Moreover, this is the first time they have seen an angklung performance live.

- Perceived Novelty. SAU always upgrade tehir performance. For instance like the the song that is booming now (Angklung instuctor, Atika Bestari,on 
April 20th, 2020). Furthermore, even in the puppet (wayang golek) show, the puppeteer updated the news or even jokes that are hot.

- Perceived opportunities for social interaction In art performances at SAU, there is a part where the visitors dance together and there is a social interaction between the dancers and the audience, even between the audience and the audience who come from different groups.

- Perceived Local Hospitality When we are going to play angklung together, children from SAU who are the local residents at Padasuka village distribute angklung to all visitors. So even when they have finished, the children scrambled to take back the angklung. We can feel the warmth of the children when they distribute the angklung one by one

- Serendipity and Surprises. One of the perceived serendipities is when a procession enters, where the procession involves quite a lot of performers. Not to mention the added cute little boy who was stretched as if he was having a circumcision. Another thing that was quite a surprise was when all the visitors had the opportunity to play the angklung directly together and make good song harmonies.

- Perceived profesionalism of local guides. Saung Angklung Udjo has a guide who speaks two languages, Indonesian and English. It proves that SAU has a competent and professional guide, which is very important because the show guide is the "face" of the initial appearance. Moreover, language mastery needs to be considered because many foreign tourists come to visit.

\section{CONCLUSION}

It can be said that the memorable tourism experience at Saung Angklung Udjo influenced by art performances, especially for tourists outside the region. A valuable experience where they can feel, do, see and hear something new, which would be difficult for them to get in their home area. The interesting factor that attracts visitors to recommend Saung
Angklung Udjo to others and their relatives is due to their impressive experiences when interacting with other visitors, and seeing Saung Angklung Udjo which is iconic and beyond their expectations.

\section{REFERENCES}

[1] R.M. Soedarsono, Seni Pertunjukan Indonesia Di Era Global. Yogyakarta: Gadjah Mada University Press, 1998.

[2] T. Narawati, Tari Sunda: dulu, kini, dan esok. Bandung: Pusat Penelitian dan Pengembangan Pendidikan Seni Tradisional, Universitas Pendidikan Indonesia, 2005

[3] Y. Yulianto, "Kreasi Seni Sebagai Daya Tarik Wisata Budaya Di Padepokan Bagong Kussudiarja YOGYAKARTA,” Media Wisata, vol. 13, no. 1, 2015.

[4] J. Masunah, Angklung di Jawa Barat: sebuah perbandingan, vol. 1. Bandung: P4ST UPI, 2003.

[5] L.-L. Chang, K.F. Backman, and Y.C. Huang, "Creative tourism: preliminary examination of creative tourists' motivation, experience, perceived value and revisit intention," Int. J. Cult. Tour. Hosp. Res., vol. 8, no. 4, pp. 401-419, 2014.

[6] E. Cohen, "Who is a tourist?: A conceptual clarification," Sociol. Rev., vol. 22, no. 4, pp. 527-555, 1974.

[7] S. Dolnicar, "Strategic Brand Image Analysis for Heteregeneous Markets." Melbourne: Univesity of Wollongong, Deakin University, 2002

[8] B. McKercher and H. Du Cros, Cultural tourism: The partnership between tourism and cultural heritage management. Routledge, 2002

[9] L. Chandralal and F.-R. Valenzuela, "Exploring memorable tourism experiences: Antecedents and behavioural outcomes," J. Econ. Bus. Manag., vol. 1, no. 2, pp. 177-181, 2013.

[10] J.W. Creswell, "Research design pendekatan kualitatif, kuantitatif, dan mixed," Yogyakarta: Pustaka Pelajar, 2010.

[11] W.L. Neuman, Metodologi Penelitian Sosial Pendekatan Kualitatif dan Kuantitatif Edisi 7. Jakarta: Indeks, 2013.

[12] Kusmayadi and E. Sugiarto, Metodologi Penelitian Dalam Bidang Kepariwisataan. Jakarta: PT. Gramedia Pustaka Utama, 2000.

[13] D. Bodger, "Leisure, learning, and travel," J. Phys. Educ. Recreat Danc., vol. 69, no. 4, pp. 28-31, 1998.

[14] A.S. Herlandra, Tari Topeng Kandaga Karya Abah Sardi Di Saung Angklung Udjo. Bandung: Universitas Pendidikan Indonesia, 2017.

[15] J. Masunah, "Pemuliaan Angklung melalui Model Desa Binaan Berbasis Wisata Seni dan Budaya," Panggung, vol. 22, no. 1, 2015.

[16] R. Sihite, Tourism Industry. Surabaya: Penerbit SIC, 2000. 